\title{
An Enhanced Solar Hybrid Brayton and Rankine Cycles with Integrated Magnetohydrodynamic Conversion System for Electrical Power Generation
}

\author{
Ayokunle Oluwaseun Ayeleso* and Atanda Kamoru Raji \\ Department of Electrical, Electronic \& Computer Engineering, Cape Peninsula University of Technology, P. O. Box 1906, Bellville 7535, \\ Cape Town, South Africa
}

\begin{abstract}
In many developing countries, the use of conventional power plants to generate electricity is not meeting the increasing demands. Therefore, it has become important to find sustainable alternatives. In the present study, a solar hybrid combined cycle power plant consisting of a solar thermal plant, large-scale gas and steam turbines, and a magnetohydrodynamic generator has been investigated under oxy-fuel combustion. The performance analysis of this system under fuel pressure rate varying from 10 to 25 bar was conducted using Cycle Tempo software. The analysis of the gas and steam combined cycle shows that the net powers and the net efficiencies obtained ranged from $98 \mathrm{MWe}$ to $134 \mathrm{MWe}$ and $30.5 \%$ to $40 \%$, respectively. In addition, the integration of the magnetohydrodynamic generator to the combined cycle led to an increase in the overall power from 169 MWe to 205 MWe. Moreover, it is seen that the fuel mass rate (2.81 $\mathrm{kg} / \mathrm{s}$ ) obtained in the gas turbine system under oxy-fuel combustion is significantly reduced when compared to conventional systems. The incorporation of solar energy and oxy-fuel combustion in the gas turbine system has increased the combustor inlet and outlet temperature and reduced the fuel consumption. From these observations, the solar hybrid system proposed in this study does not only generates electric power but also reduce the turbine exhaust fumes and $\mathrm{CO}_{2}$ emissions, which is a key factor in minimizing environment pollution.
\end{abstract}

Keywords: Solar thermal plant, Oxy-fuel combustion, Gas and Steam Turbines, Magnetohydrodynamic generator, power.

Article History: Received: $11^{\text {th }}$ December 2020; Revised: $16^{\text {th }}$ April 2021; Accepted: $8^{\text {th }}$ May 2021; Available online: $20^{\text {th }}$ May 2021

How to Cite This Article: Ayeleso, A.O. and Raji, A.K. (2021). An Enhanced Solar Hybrid Brayton and Rankine Cycles with Integrated Magnetohydrodynamic Conversion System for Electrical Power Generation. Int Journal of Renewable Energy Development, 10(4), 755-767 https://doi.org/10.14710/ijred.2021.34927

\section{Introduction}

In the past decades, the use of fossil fuels has contributed to an increase in pollution, human and ecosystem toxicity, acidified land, and particle formation. Aside from this, fossil fuels availability is depleting very fast and can no longer meet the increasing electricity demands, especially in developing countries. Thus, integrating environmentally friendly renewable energy sources (solar energy) and oxy-fuel combustion into conventional power plants could help countries achieving their energy requirements (Allam et al. 2013; Eason et al. 2016; Hoseinzadeh et al. 2020a; Hoseinzadeh et al. 2020b). Solar power tower (SPT) plant, also known as concentrated solar power (CSP) is one of the main alternative renewable energy technologies used for the production of heat and generation of electricity. According to Poživil et al. (2014), an SPT plant consists of two-axis tracking specular mirrors (heliostats), which capture and concentrate solar energy to a central receiver system (CRS). The CRS is placed on top of a fixed solar tower where liquid and gases are heated at high temperatures. The preheated fluids are either injected into a gas turbine (GT) or a steam turbine (ST) to generate electricity (Kalogirou 2011; Wallentinsen 2016). Furthermore, the CRS can be design in a tubular or pressurized volumetric shape (Malan 2014; Augsburger 2015). The heat transfer fluid (HTF) commonly used in tubular receivers are synthetic oil, water, molten salt, liquid sodium and particles. In volumetric receivers, air and carbon dioxide $\left(\mathrm{CO}_{2}\right)$ mediums are common (Zhang et al. 2013). Comparing these receivers, the volumetric type can heat fluids to temperatures between $800^{\circ} \mathrm{C}$ and 1000 ${ }^{\circ} \mathrm{C}$ at 10 bar, with an efficiency of about 78\% (Hischier et al. 2009; Ho et al. 2009; Vogel 2010; Kalogirou 2011; Augsburger 2013; Behar et al. 2013; Ho and Iverson 2014; EL Hassani et al. 2020).

Several studies in the literature have reported on the incorporation of solar thermal systems to the conventional power plants (Buck et al. 2002; Heller et al. 2006; Garcia et al. 2008; Jabbar 2014; Saghafifar and Gadalla 2016; EL Hassani et al. 2020).

Antonanzas et al. (2014) examined the potential for solar thermal integration in 51 combined cycle gas turbines (CCGTs) under different operational settings in mainland Spain. They found that the overall efficiency of the plant decreases as solar air temperature increases.

Korzynietz et al. (2016) investigated the integration of a megawatt (MW)-scale solar hybrid plant (Solugas) to a solarised GT system. The solar plant uses a tubular

\footnotetext{
* Corresponding author: Ayelesoa@cput.ac.za
} 
receiver which temperature is at $800^{\circ} \mathrm{C}$. It was tested with the Mercury 50 $0^{\mathrm{TM}}$ GT for more than 1000 hours in San Lucar la Mayor, Spain. The turbine generates a power capacity of $4.6 \mathrm{MWe}$, with an efficiency of $38.5 \%$.

Petrakopoulou et al. (2017) investigated the integration of a pressurised volumetric solar receiver to a small-scale (Mercury 50 $0^{\mathrm{TM}} \mathrm{GT}$ ) and a large-scale (Siemens SGT5-4000F combined cycle) power plants. Their results showed that the energy efficiencies of the plants slightly decreased with increasing air temperature (from $800^{\circ} \mathrm{C}$ to $1000^{\circ} \mathrm{C}$ ) at the inlet of the GT combustors. They concluded that the above method reduces the fuel mass rate in the combustor. Table 1 presents a summary of typical SPT receivers that were previously integrated to the conventional GT plants.

Several studies have also reported that the use of Oxygen Enhanced Combustion (OEC) (i.e., fuel is burned with pure oxygen $\left(\mathrm{O}_{2}\right)$ instead of air) in the GT cycle help to reduce exhaust gas volume. In addition, it reduces fuel consumption, reduce $\mathrm{CO}_{2}$ emission, increase the potential for carbon capture and may further enhance the overall cycle efficiency (Anderson et al. 2008; Hong et al. 2009; Ferrari et al. 2017; Kotowicz et al. 2019; Nowak et al. 2019).

Nowak et al. (2019) performed a study to analyse the combustion behavior of a micro-oxy GT system. In their results, an increase in the oxygen concentration led to an increase in the temperature of the combustion chamber and the power delivered by the turbine.

Dumitrascu et al. (2001) investigated alternative ways to decrease the effects of temperature variation in the air intake compressor of a GT cycle in a cogeneration power plant. Their results showed that adiabatic humidification is an effective cooling mechanism (about $100^{\circ} \mathrm{C}$ ) to reduce compressor work. Moreover, the increased concentration of oxygen in the air led to a significant increase of the overall heat after the combustion process.

In another study, Horbaniuc et al. (2004) studied the effects of increased $\mathrm{O}_{2}$ concentration (from 21 to 100\%) in a supercritical steam boiler of a natural gas power plant. The results were compared with a boiler operating under conventional combustion ( $79 \%$ Nitrogen, $21 \% \mathrm{O}_{2}$ ) in the air. They concluded that an increase in the $\mathrm{O}_{2}$ fraction raises the flue gas temperature. In this way, the heat transfer surfaces could be reduced because of the higher mean-log temperature differences in the heat exchangers of the boiler.
Baskar et al. (2016) performed an experimental test to study the effects of $\mathrm{O}_{2}$ enrichment (from 21 to $27 \%$ in the intake air) in a cylinder-shaped diesel engine. They found that the combustion process increases the thermal efficiency of the engine from 4 to $8 \%$. This process also decreases the brake specific fuel consumption from 5 to $12 \%$. The drawback of this method is that there is an increase in nitrogen oxide emissions due to the increased combustion temperature.

Despite the insights gained through previous research, reports are sparse on the effect and collective use of solar thermal plants and oxy-fuel combustion in a combined cycle, and on the operation of Brayton cycle (BC), Rankine cycle (RC), and magnetohydrodynamic (MHD) generator cycle. Little is known about the influence of exhaust temperature, and other operating parameters on the efficiency of these cycles when oxy-fuel combustion is employed. Therefore, the present work aims to contribute to addressing these gaps. The focus is to determine whether the utilization of solar energy and oxy-fuel combustion has a significant effect on the performance of GT, ST, and MHD generator cycles. The energy performance of the GT and ST systems is analysed using Cycle Tempo software. The results are compared to the airfuel combustion case to demonstrate possible benefits and drawbacks. The MHD generator cycle is analysed through theoretical modelling to evaluate the energy performance of the system.

\section{System Configuration}

The hybrid system considered in the present study consists of a solar energy receiver (pressurized volumetric shape), a combined cycle power plant (GT and ST) and an MHD generator, as shown in Figure 1. From the solar energy receiver, hot air is transferred to the non-contact heat exchanger (NCHE) of a GT. In addition, compressed air, or pure oxygen flow simultaneously to the NCHE, where it is preheated before reaching the combustor unit. Typically, natural gas-fired powered plants utilize air-fuel combustion $\left(79 \%\right.$ Nitrogen, $\left.21 \% \mathrm{O}_{2}\right)$. In this study, we introduce pure oxygen as the only oxidant in the combustion process (Poživil et al. 2014; Bedick et al. 2017; EL Hassani et al. 2020). In the combustor, under constant pressure, the fluid is mixed with a small quantity of methane and the heated flue gas obtained expands in the GT.

Table 1

\begin{tabular}{|c|c|c|c|c|}
\hline Literature & $\begin{array}{c}\text { Air receiver } \\
\text { Type }\end{array}$ & $\begin{array}{c}\text { Receiver Temp } \\
{\left[{ }^{\circ} \mathrm{C}\right]}\end{array}$ & $\begin{array}{c}\text { Pressure } \\
\text { [Bar] }\end{array}$ & GT Power [MW] \\
\hline (Buck et al. 2002) & Pressurised volumetric & 800 & 15 & 0.24 \\
\hline Solgate: (Heller et al. 2006) & Pressurised volumetric & 800 & $6.5-8$ & 0.23 \\
\hline (Garcia, et al. 2008) & Pressurised volumetric & $750-950$ & $6-8$ & 1.4 \\
\hline Solugas: (Korzynietz et al. 2016) & Pressurised Tabular & 800 & 9 & 4.6 \\
\hline (Petrakopoulou et al. 2017) & Pressurised volumetric & 800 & 8.8 & 4.6 \\
\hline
\end{tabular}




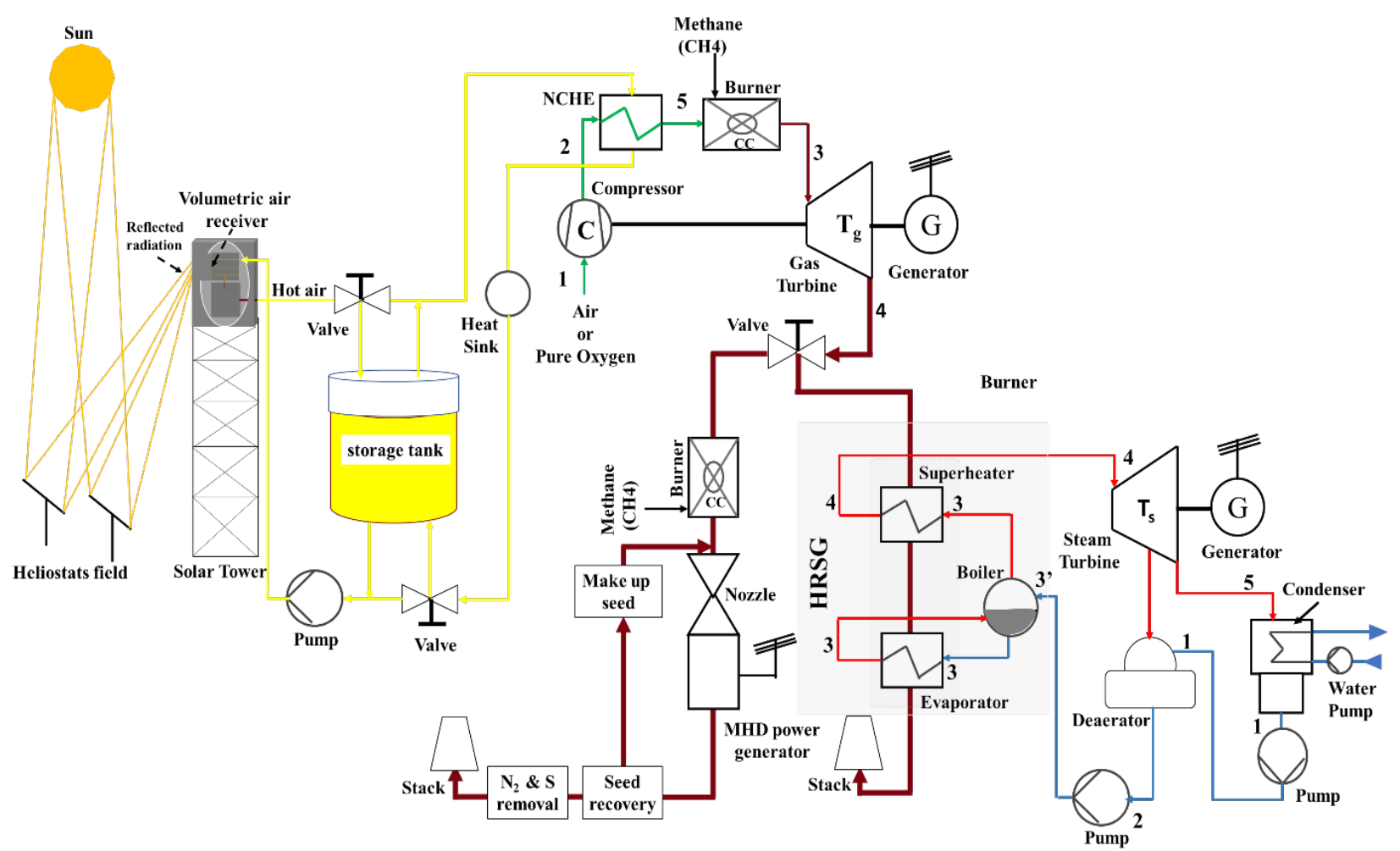

Fig. 1 Schematic diagram of the solar hybrid combined cycle power plant and MHD generator

The turbine shaft drives the generator to produce electricity, with a slight loss of energy due to mechanical (auxiliary), piping and storage systems (Pitz-Paal et al. 2005; Amelio et al. 2014; Augsburger 2015; Manente 2016; Buck et al. 2017). The GT exhaust is also connected to a valve that shares the flue gas flow rate between the bottom $\mathrm{RC}$ and MHD generator cycle to form a triple combined cycle. In the $\mathrm{RC}$, the heat recovery steam generator (HRSG) produces the high steam temperature required in the ST. The superheated steam is then rotated by the turbine blades for electric power generation. Figure 1 depicts the schematic diagram of the solar hybrid combined cycle power plant and MHD generator (SHCCPPM).

\section{Thermodynamic Principles of the Triple Combined Cycle}

This section describes the governing equations used for the evaluation of the triple combined cycle considered in the present study.

\subsection{Gas turbine cycle}

The GT cycle consists of five major components: a compressor, a heat exchanger, a combustor, a turbine, and a generator (Figure 1). The turbine operates based on the principles of the Brayton cycle and the temperatureentropy (T-s) is shown in Figure 2.

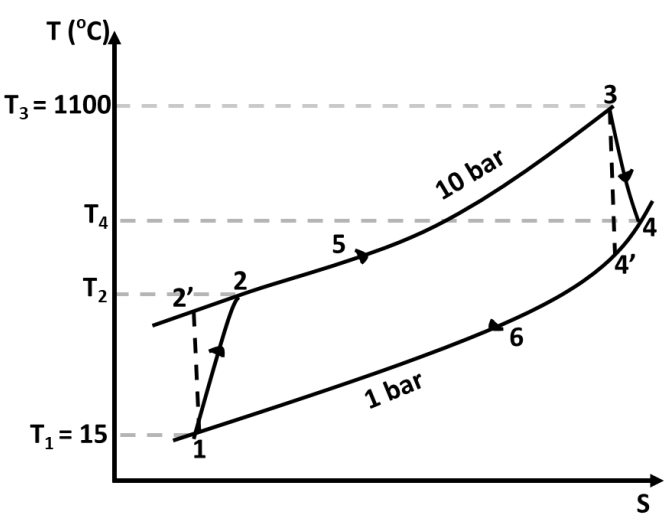

Fig. 2 T-s diagram of the Brayton cycle

The Brayton cycle in Figure 2 is composed of five major processes:

i) Process 1-2 is the isentropic compression in the compressor.

ii) Process 2-5 is the preheating of compressed air or oxygen in the NCHE.

iii) Process 5-3 is the addition of heat at constant pressure in the combustion chamber (CC).

iv) Process 3-4 is the isentropic expansion in the turbine.

v) Process $4-1$ is the rejection of heat at constant pressure. 
The temperature-entropy of the Brayton cycle is usually defined in terms of the compressor inlet pressure, $\mathrm{P}_{1}$, and temperature, $\mathrm{T}_{1}$. The compressor pressure ratio, $r_{c}$, is the ratio between $\mathrm{P}_{1}$ and compressor outlet pressure, $\mathrm{P}_{2}$. The pressure loss in the combustion chamber is represented by $\mathrm{P}_{2}-\mathrm{P}_{3}$, while in the turbine, it is represented by $\mathrm{P}_{4}-\mathrm{P}_{1}$. For process 1-2, the compressor exit temperature, $\mathrm{T}_{2}$, is given by (Oyedepo et al. 2017),

$T_{2}=T_{1} \cdot\left(1+\frac{r_{c}^{\frac{\gamma a-1}{\gamma a}}-1}{\eta_{c}}\right)$

where $\eta_{c}=T_{2}{ }^{\prime}-T_{1} / T_{2}-T_{1}$ is the compressor isentropic efficiency, $T_{1}$ and $T_{2}$ are the compressor inlet and outlet temperatures, $T_{2}{ }^{\prime}$ is the compressor isentropic outlet temperature and $\gamma_{a}=1.4$ is the heat capacity ratio for air or pure oxygen.

The reversible adiabatic expansion, $T_{4}{ }^{\prime}$, and the actual turbine discharge temperature, $T_{4}$, are given by (Oyedepo et al. 2017; Rahman et al. 2011),

$T_{4}^{\prime}=\frac{T_{3}}{r_{c}^{\frac{\gamma g-1}{\gamma g}}}$,

$T_{4}=T_{3}-\eta_{T} \cdot\left(T_{3}-T_{4}{ }^{\prime}\right)$,

where $T_{3}$ is the temperature of flue gas after combustion, $\gamma_{g}=1.33$ is the heat capacity ratio for flue gas and $\eta_{T}$ is the isentropic efficiency of turbine.

For process 2-5, the temperature at the heat exchanger (NCHE) is given by,

$T_{5}=T_{2}+\eta_{N C H E}\left(T_{4}-T_{2}\right)$.

For process 3-4, the heat, $Q_{G T}$, supplied to the cycle after turbine isentropic expansion is given by (Kayabasß1 et al. 2017; Kadhim et al. 2019),

$Q_{G T}=m_{a} \cdot c p_{a} \cdot\left(T_{3}-T_{2}\right)$,

where $m_{a}$ is the mass flow rate for air or pure oxygen, $c p_{a}=$ $1.005 \mathrm{~kJ} / \mathrm{kg} . \mathrm{K}$ is the specific heat for air or pure oxygen and $\eta_{N C H E}$ is the heat exchanger efficiency.

The work consumed in the compressor, $W_{\mathrm{C}}$, when ambient air or pure oxygen goes through isentropic compression (process 1-2) is given by,

$W_{C}=c p_{a} \cdot\left(T_{2}-T_{1}\right)$.

The work produced in the turbine, $W_{\mathrm{GT}}$, when flue gas goes through isentropic expansion (process $3-4$ ) is given by (Kayabasßr et al. 2017; Kadhim et al. 2019),

$W_{G T}=c p_{g} \cdot\left(T_{3}-T_{4}\right)$,

where $c p_{g}=1.15 \mathrm{~kJ} / \mathrm{kg} . \mathrm{K}$ is the specific heat capacity of flue gas.

The work ratio, $W_{\text {ratio }}$, is given by,
$W_{\text {ratio }}=\frac{W_{G T}-W_{C}}{W_{G T}}$.

The total work, $W_{\text {net_GT }}$, in the cycle is the difference between the work consumed by the compressor and the work produced by the turbine, as given by (Kadhim et al. 2019),

$W_{\text {net } G T}=\left(W_{G T}-W_{C}\right)$.

The total work or power in the cycle can also be expressed as,

$W_{\text {net_GT }}=\eta_{B C} \cdot Q_{G T}$.

The thermal efficiency of the GT (BC), in terms of pressure ratio and temperature is given by,

$\eta_{B C}=1-\frac{1}{\left(r_{T}\right)^{\frac{\gamma g^{-1}}{\gamma g}}}=\frac{\left(T_{3}-T_{4^{\prime}}\right)-\left(T_{2^{\prime}}-T_{1}\right)}{\left(T_{3}-T_{2^{\prime}}\right)}$.

\subsection{Steam turbine cycle}

The ST cycle consists of a condenser, feedwater pumps (1 \& 2), a deaerator, a boiler, an evaporator, a superheater and a generator (Figure 1). The turbine operates based on the principles of Rankine cycle. The exhaust from the GT is used as the source of heat in the cycle and the temperature-entropy is shown in Figure 3 (Moran and Shapiro 2010).

The Rankine cycle in Figure 3 is composed of six major processes:

i. Process 1-2 is the isentropic compression stage, where water from the condenser vacuum flows to the deaerator through the pump 1.

ii. Process 2-3' is the pumping stage, where water from the deaerator flows into the boiler with an increased pressure through the pump 2.

iii. Process 3 '-3 is the heating process from the boiler to the evaporator at constant pressure of 80 bar. In this process, water is heated at a high temperature to become steam.

iv. Process 3-4 is another heating stage, where the steam is re-heated by the superheater and flows into the turbine.

v. Process 4-5 is the isentropic expansion stage, where the superheated steam is rotated by the ST blades and then transported to the generator to produce electric power.

vi. Process 5-1 is the condensing stage, where the steam vapor from the turbine experiences an isobaric phase change inside the condenser to become liquid again for the next round of the cycle.

The heat energy, $Q_{S T}$, flow input to the $\mathrm{RC}$ is given by,

$Q_{S T}=m_{R C}\left(h_{3}-h_{4}\right)=m_{H S} \cdot c p_{H S M}\left(T_{S}-T_{\text {exit }}\right)$.

The work produced in the turbine, $W_{S T}$, is given by (Tchanche et al. 2013; Nurhilal et al. 2016),

$W_{S T}=m_{R C} \cdot\left(h_{4}-h_{5}\right)$. 


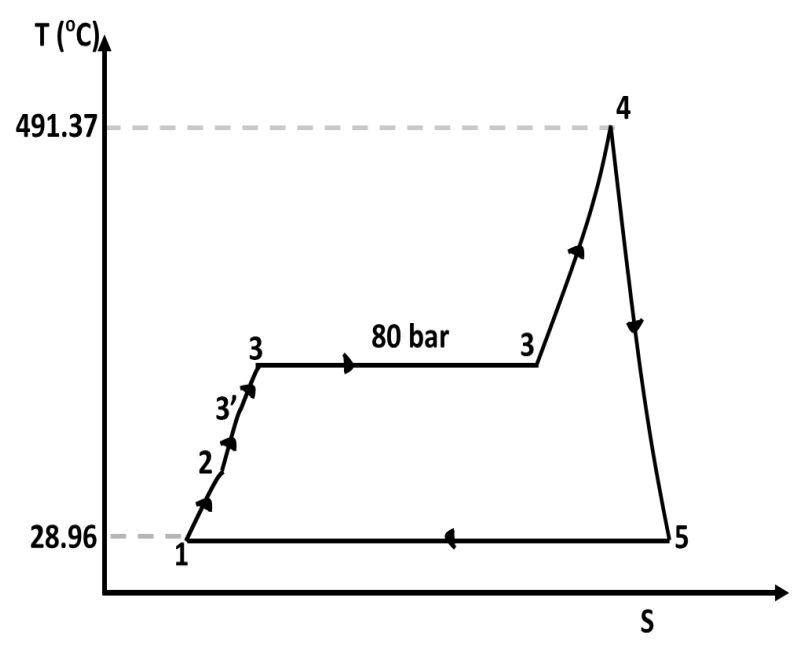

Fig. 3 T-s diagram of the Rankine cycle

The work produced by the pump, $W_{P}$, is given by,

$W_{P}=m_{R C} \cdot\left(h_{3}-h_{1}\right)$.

The total work, $W_{\text {net_sT }}$, in the cycle is given by (Tchanche et al. 2013; Nurhilal et al. 2016),

$W_{\text {net_ST }}=W_{S T}-W_{P}$,

$W_{\text {net_ST }}=m_{R C} \cdot\left[\left(h_{4}-h_{5}\right)-\left(h_{3}-h_{1}\right)\right]$,

where $m_{R C}$ is the mass flow rate to $\mathrm{RC}, m_{H S}$ is the mass flow rate of heat carrier (flue gas), $c p_{H S M}$ is the specific heat capacity of the heat source medium, $T_{s}$ is the inlet temperature, $T_{\text {exit }}$ is the exit temperature, $h_{1}$ is the entalphy of pump, $h_{3}$ is the entalphy of preheaters, $h_{4}$ is the entalphy of turbine and $h_{5}$ is the entalphy of condenser.

The thermal efficiency of the ST (RC) is given by (Tchanche et al. 2013; Nurhilal et al. 2016),

$\eta_{R C}=\frac{W_{n e t} S T}{Q_{S T}}$.

The net power and efficiency of the combined cycle (GT and ST) are given by (Rajesh and Kishore 2018),

$W_{C C}{ }^{n e t}=W_{G T}+W_{S T}-W_{A U X}$,

$\eta_{C C}{ }^{n e t}=\left(\frac{W_{G T}+W_{S T}}{Q_{G T}+Q_{S T}}\right) \times 100$,

where $W_{G T}$ is the gas turbine work, $W_{S T}$ is the steam turbine work, $W_{A U X}$ is the auxiliary (mechanical) work, $Q_{G T}$ is the heat supplied to the gas turbine and $Q_{S T}$ heat supplied to the steam turbine.

\subsection{MHD generator cycle}

\section{- Description of the MHD system}

The MHD generator can be designed as an open-cycle (hot flue gas is exhausted to the atmosphere), a closed-cycle (transfer of heat occurs through heat exchangers) and a liquid metal. The open cycle MHD system is implemented in this study. The system operates based on the principles of the law of electromagnetic induction in which a primary fluid is seeded with an alkali metal and burned in a combustor. The alkali metal mixes with the gaseous combustion products to produce a very hot fluid that contains a large number of electrically conducting charged particles (Bedick et al. 2017). This stream of charged particles (positively and negatively) escape from the combustor through a nozzle at high velocity, $v$. The charged particles are directed to transverse a very large and powerful electromagnet. This process forced them to move in opposite directions and are subsequently captured by the generator electrodes. The direct current obtained from the electrode terminals is converted to an alternating current that is compatible with power utility systems (Ajith and Jinshah 2013). Thereafter, the seed material is recovered from the generator exhaust by removing harmful emissions such as nitrogen and sulphur. The exhaust is discharged to the atmosphere through a stack (Figure 1). In principle, the generator open-circuit voltage, $\mathrm{V}$, is a function of the fluid velocity, the distance between the electrodes, $l$, and the magnetic flux density, B, as given by (Ajith and Jinshah 2013; Poonthamil et al. 2016),

$$
\begin{aligned}
& \mathrm{V}=(v l B) . \\
& V_{\text {max }}=(v l B)-I_{\text {max }}\left(R_{I}\right) .
\end{aligned}
$$

The current flowing inside the MHD generator is given by,

$I=\frac{\mathrm{V}}{R_{I}+R_{L}}$.

The electric power, $P_{\text {out }}$, that can be obtained from the external load resistor connected to the electrodes is given by (Takayanagi et al. 2014; Anumaka 2014),

$P_{\text {out }}=\sigma v^{2} \mathrm{~B}^{2} A l \cdot k(1-k)$.

From Equation 22, when the load factor $(0 \leq k \leq 1)$ is approximately 0.5 , the internal resistance of the generator equals the external load resistance. Hence, the maximum power, $P_{\max }$, that can be extracted is given by (Kayukawa 2004; Sivaram et al. 2015),

$P_{\text {out }}=\sigma v^{2} \mathrm{~B}^{2} A l \cdot \frac{1}{2}\left(1-\frac{1}{2}\right)=\frac{\sigma v^{2} \mathrm{~B}^{2} A l}{4}$.

The conversion efficiency, $\eta$, of the MHD generator is given by,

$\eta=\frac{V_{\max }}{v B}$

where $\sigma$ is the fluid electrical conductivity, $v$ is the fluid velocity, $B$ is the magnetic flux density, $V_{\max }$ is the maximum voltage, $I_{\max }=v B A \sigma / 2$ is the maximum current, $l$ is the distance between the electrodes, $A$ is the electrode surface area, $R_{L}$ is the external load resistance and $R_{I}=l / \sigma A$ is the internal resistance, $k=$ $R_{L} /\left(R_{I}+R_{L}\right)=0.5$ is the electrical load factor. 


\section{- Theoretical modelling of the MHD generator}

The GT exhaust flue gas is the primary heat transfer fluid required for modelling the MHD generator in the present hybrid system setup. The flue gas is mixed with a small quantity of methane and seeded with about $1 \%$ of potassium carbonate inside a burner to increase the temperature and electrical conductivity (Figure 1). In addition, the exhaust flue gas after combustion passes through a convergent-divergent (C-D) nozzle to increase the velocity to an optimum level before entering the MHD generator. To investigate the behaviour of the exhaust gas flowing in the C-D nozzle, a computational fluid dynamic (CFD) simulation is performed using Ansys Fluent Software. Figure 4 depicts the mesh and design geometries of the nozzle. For the simulation setup, a quadrilateralshaped mesh grid consisting of 23400 nodes and 23014 elements. This mesh size is adopted to optimize the CPU $(2.3 \mathrm{GHz})$ time and cost of computations. Table 2 presents the flue gas parameters, and the nozzle boundary conditions.

In order to evaluate the energy performance of the MHD generator, the C-D nozzle maximum velocity, along with the parameters presented in Table 3, will be used for a theoretical modelling of the system (Equations 23 and 24) (Parsodkar 2015; Ayeleso and Kahn 2018).

Table 2

The flue gas parameters and the C-D nozzle boundary conditions

\begin{tabular}{ll}
\hline General & Solver Type: Density-Based, \\
setup & 2D Space: Planar, \\
& Time: Steady \\
& Velocity formulation: Absolute. \\
Models & Energy equation: On \\
& Viscous model: Standard k-epsilon model, \\
& Standard Wall Function; Species transport. \\
Materials & Fluid species: Methane $(5 \%)$, flue gas $(95 \%)$. \\
& Density: Ideal gas, \\
& Viscosity $=1.72 \mathrm{e}-05 \mathrm{Kg} / \mathrm{m}-\mathrm{s}$, \\
& Thermal conductivity $=0.0454 \mathrm{~W} / \mathrm{m}-\mathrm{K}$, \\
& Mass diffusivity $=2.88 \mathrm{e}-05 \mathrm{~m} 2 / \mathrm{s}$. \\
Boundary & Inlet: Pressure-Inlet, \\
conditions & Gauge Total Pressure $=1.013 \mathrm{e} 5 \mathrm{~Pa}$, \\
& Initial Gauge Pressure $=50662 \mathrm{~Pa}$ \\
& Inlet Temperature $=2600 \mathrm{~K}=2326.85{ }^{\circ} \mathrm{C}$, \\
& Outlet: Pressure-Outlet, \\
& Gauge Pressure $=3738.9 \mathrm{~Pa}$, \\
& Outlet Temperature $=2600 \mathrm{~K}$
\end{tabular}

Table 3

Modelling parameters for the MHD generator

\begin{tabular}{ll}
\hline MHD generator parameter & Value \\
\hline Magnetic flux density (B) & 2.5 Tesla \\
Flue gas electrical conductivity $(\sigma)$ & $10 \mathrm{~S} / \mathrm{m}$ \\
Surface area of the electrode $(\mathrm{A})$ & $1 \mathrm{~m}^{2}$ \\
Distance between the electrodes $(l)$ & $1 \mathrm{~m}$ \\
Generator Internal resistance $\left(R_{I}\right)$ & $0.1 \Omega$ \\
External resistor $\left(R_{L}\right)$ & $0.1 \Omega$ \\
\hline
\end{tabular}

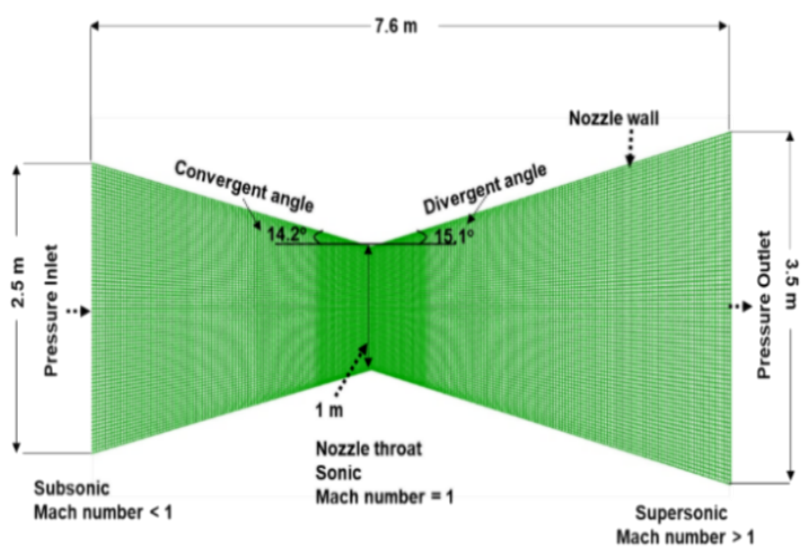

Fig. 4 C-D nozzle mesh and design geometries

\section{Results and Discussion}

This section presents the energy performance analysis of the SHCCPPM.

\subsection{Modelling results of the Mercury 50TM GT system}

The configuration of the GT system in the present study is based on the MW-class Mercury 50TM GT model developed by Solar Turbines. This plant has been used in several applications which deal with solar hybrid cycles. The design point parameters of the Mercury 50TM GT are sourced from available literature and used to validate the energy performance under air-fuel and oxy-fuel combustion processes. The Mercury 50 TM GT plant has a turbine inlet temperature close to $1160{ }^{\circ} \mathrm{C}$. The isotropy efficiencies of the plant which is at $86 \%$ are considered to be at mid-range, with a single stage cooling (Spelling 2013). The turbine mechanical efficiencies are estimated to be at $95.7 \%$. The energy performance results obtained using Cycle Tempo software are reasonably accurate and are comparable to the values reported in literature (Lundberg et al. 2003; Song et al. 2006; Giuliano et al. 2008; Kalina 2012; Korzynietz et al. 2016; Petrakopoulou et al. 2017).

When the Mercury 50 $0^{\mathrm{TM}}$ GT operates under air-fuel combustion, the modelling results (Table 4 and Figure 5) obtained through Equations 9, 10 and 11 indicate that the generator produces a gross power of 4.6 MWe and a net efficiency of $38.5 \%$. The turbine exhaust flue gas temperature $\left(663.3{ }^{\circ} \mathrm{C}\right)$ is comparable to temperatures $\left(640^{\circ} \mathrm{C}\right.$ and $662{ }^{\circ} \mathrm{C}$ ) reported by (Song et al. 2006; Kalina 2012). Conversely, under oxy-fuel combustion conditions, the plant generates a gross power of $4.2 \mathrm{MWe}$ and a net efficiency of $35.9 \%$ (Table 4). The turbine exhaust temperature is increased to $679.9^{\circ} \mathrm{C}$, while keeping lower fuel consumption rate.

Comparing the above results, the GT exhaust temperature obtained under oxy-fuel combustion is relatively higher than the temperature obtained under airfuel combustion (Table 4). This observation correlates well with the findings of Self et al. (2018), which demonstrate an increased $\mathrm{CO}_{2}$ content in the turbine exhaust. On the other hand, the fuel mass rate, gross power, and net efficiency are slightly higher under air-fuel combustion conditions. 
Table 4

Specifications of the Mercury $50^{\mathrm{TM}}$ GT plant: Results of performance analysis based on standard and predicted values Descriptions Mercury 50 ${ }^{\mathrm{TM}}$ GT (air-fuel) Mercury 50 ${ }^{\text {TM }}$ GT (oxy-fuel)

\section{Compressor}

Inlet temperature $\left({ }^{\circ} \mathrm{C}\right)$

Pressure ratio (bar)

Mass rate $(\mathrm{kg} / \mathrm{s})$

Exit temperature $\left({ }^{\circ} \mathrm{C}\right)$

Isentropic efficiency (\%)

Mechanical efficiency (\%)

15.05
9.9
17.8
318.55
86
95.7

95.7

596.31

9.67

Exit temperature $\left({ }^{\circ} \mathrm{C}\right)$

Exit pressure (bar)

\section{Combustor}

Fuel temperature $\left({ }^{\circ} \mathrm{C}\right)$

Fuel mass rate $(\mathrm{kg} / \mathrm{s})$

Low heating value (kJ/kg)

Fuel pressure (bar)

Exit temperature $\left({ }^{\circ} \mathrm{C}\right)$

Exit pressure (bar)

\section{Turbine}

Inlet temperature $\left({ }^{\circ} \mathrm{C}\right)$

Exhaust temperature $\left({ }^{\circ} \mathrm{C}\right)$

Isentropic efficiency (\%)

Mechanical efficiency (\%)

\section{Generator}

Gross power (MWe)

Net efficiency (\%)
25 (Standard gas)

0.34

47100

9.08

1160

8.81

1160

663.3

86

95.7

4.6

38.5
15.05

9.9

17.8

308.09

86

95.7

612.88

9.66

25 (Methane)

0.24

50000

9.08

1160

8.81

1160

679.9

86

95.7

4.2

35.9

Mercury 50 $0^{\mathrm{TM}}$ GT

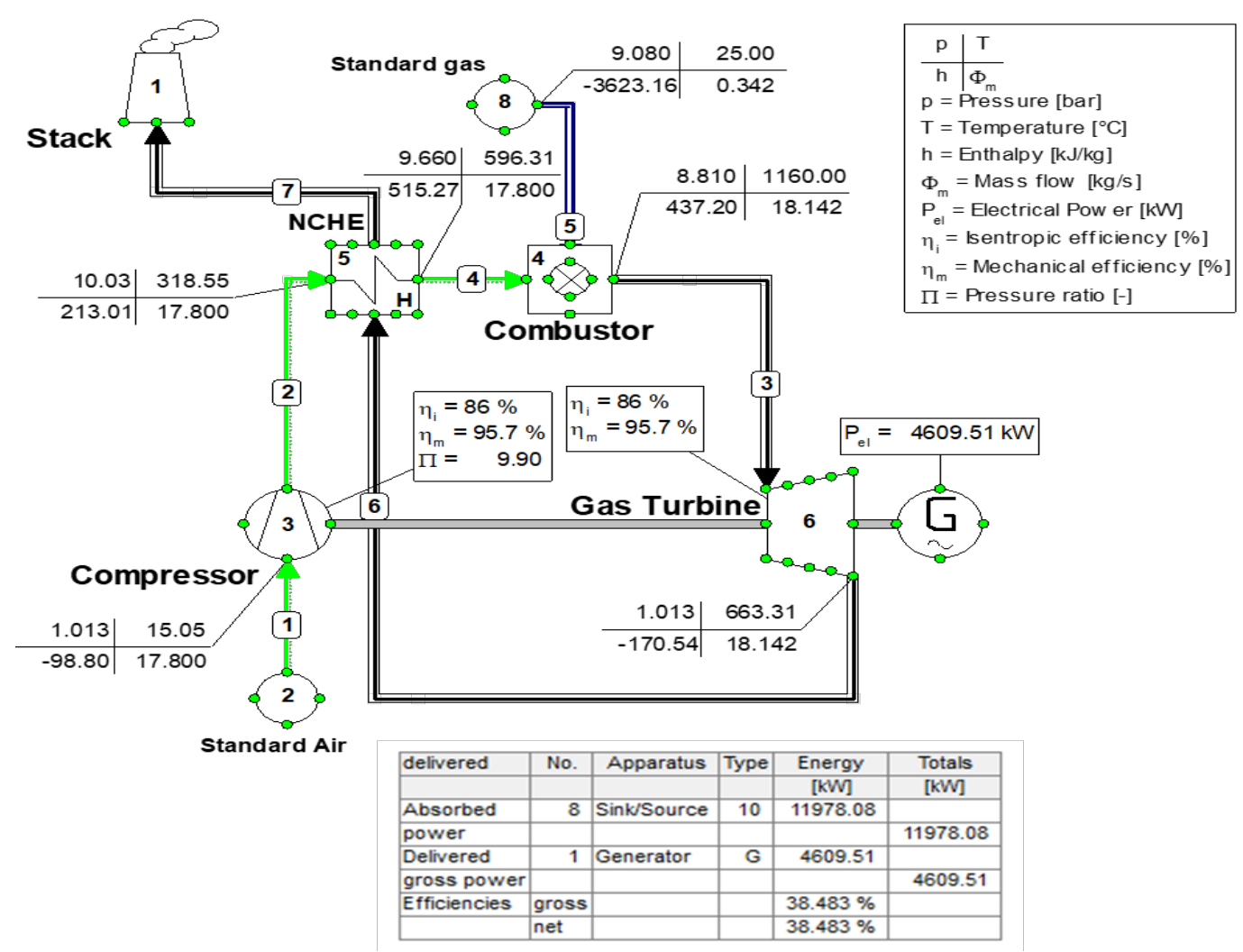

Fig. 5 Flow cycle of the Mercury $50^{\mathrm{TM}}$ GT plant 


\subsection{Modelling results of the SHCCPP system}

In a previous study, Aldali and Morad (2016) has demonstrated the advantage of coupling a solar collector to both GT and ST. In the current study, the solar hybrid combined cycle power plant (SHCCPP) consists of a ST plant and of a solar thermal plant coupled to a Mercury $50^{\mathrm{TM}}$ GT modelled under oxy-fuel combustion (Figure 6). The pressurised volumetric solar receiver parameters applied in a combined cycle incorporating a Siemens SGT5-4000F GT system (Petrakopoulou et al. 2017) is used to model the current SHCCPP system. The receiver produced an air outlet temperature of $800{ }^{\circ} \mathrm{C}$ at a thermal efficiency of $76.14 \%$. In addition, the tilting angle of the receiver is $30^{\circ}$ (Solgate Report 2005; Petrakopoulou et al. 2017). In the SHCCPP GT, the turbine inlet temperature is at $1065.35{ }^{\circ} \mathrm{C}$, while the Siemens SGT5-4000F GT is at $1547.6{ }^{\circ} \mathrm{C}$.

Figure 6 depicts the energy performance results of the SHCCPP system. In the SHCCPP, a significant amount of solar energy increased the inlet temperature of the combustor to $771{ }^{\circ} \mathrm{C}$ (mass rate of $735 \mathrm{~kg} / \mathrm{s}$ ). This results in a decreased in the net efficiency of the GT combustion process. This outcome is comparable to a combustor inlet temperature of $721.64{ }^{\circ} \mathrm{C}$ (mass rate of $748.99 \mathrm{~kg} / \mathrm{s}$ ) found in the Siemens SGT5-4000F GT under air-fuel combustion (Petrakopoulou et al. 2017). The obtained combustor inlet temperature depends on the GT size, air-to-fuel ratio and the turbine inlet temperature.

It is worth noting that the incorporation of solar energy and oxy-fuel combustion to the SHCCPP system, result in a reduced fuel mass rate $(2.81 \mathrm{~kg} / \mathrm{s})$ when compared to 15.4 $\mathrm{kg} / \mathrm{s}$ used in the Siemens SGT5-4000F GT (Petrakopoulou et al. 2017). The addition of the solar plants to these systems have proven to reduce natural gas consumption and $\mathrm{CO}_{2}$ emissions. Similar observations were found in the findings of Dumitrascu et al. (2001), Horbaniuc et al. (2004), Aldali and Morad (2016), Baskar et al. (2016), Bedick et al. (2017), Wang et al. (2018), Nowak et al. (2019) and Ahmad et al. (2020).

The net efficiency of the SHCCPP system is $36.6 \%$ (Equation 18), while the net efficiency of the Siemens SGT5-4000F hybrid power plant is $39.5 \%$. When comparing the two plants, the net efficiency of the SHCCPP system has decreased by $2.9 \%$.

The net powers delivered by the SHCCPP system at a constant fuel pressure rate of 17.5 bar is approximately 121 MWe (94 MWe GT power, 27 MWe ST power), as shown in Figure 6 and Table 5. The power delivered by the ST can be attributed to the energy extracted from the GT exhaust by superheater and evaporator to produce more steam in the HRSG. This process led to an increased ST inlet temperature of $465.53{ }^{\circ} \mathrm{C}$ using a GT exhaust temperature of $505.52{ }^{\circ} \mathrm{C}$. In the Siemens SGT5-4000F hybrid plant, a higher ST inlet temperature of $830{ }^{\circ} \mathrm{C}$ is obtained using a GT exhaust temperature of $850.4{ }^{\circ} \mathrm{C}$ (Petrakopoulou et al. 2017). Butcher and Reddy (2007) found similar results of increased steam production due to increased flue gas temperature.

From the above outcomes, the incorporation of oxy-fuel combustion in the SHCCPP system contributes significantly to the obtained GT exhaust temperature. This is beneficial to the bottom MHD generator cycle.

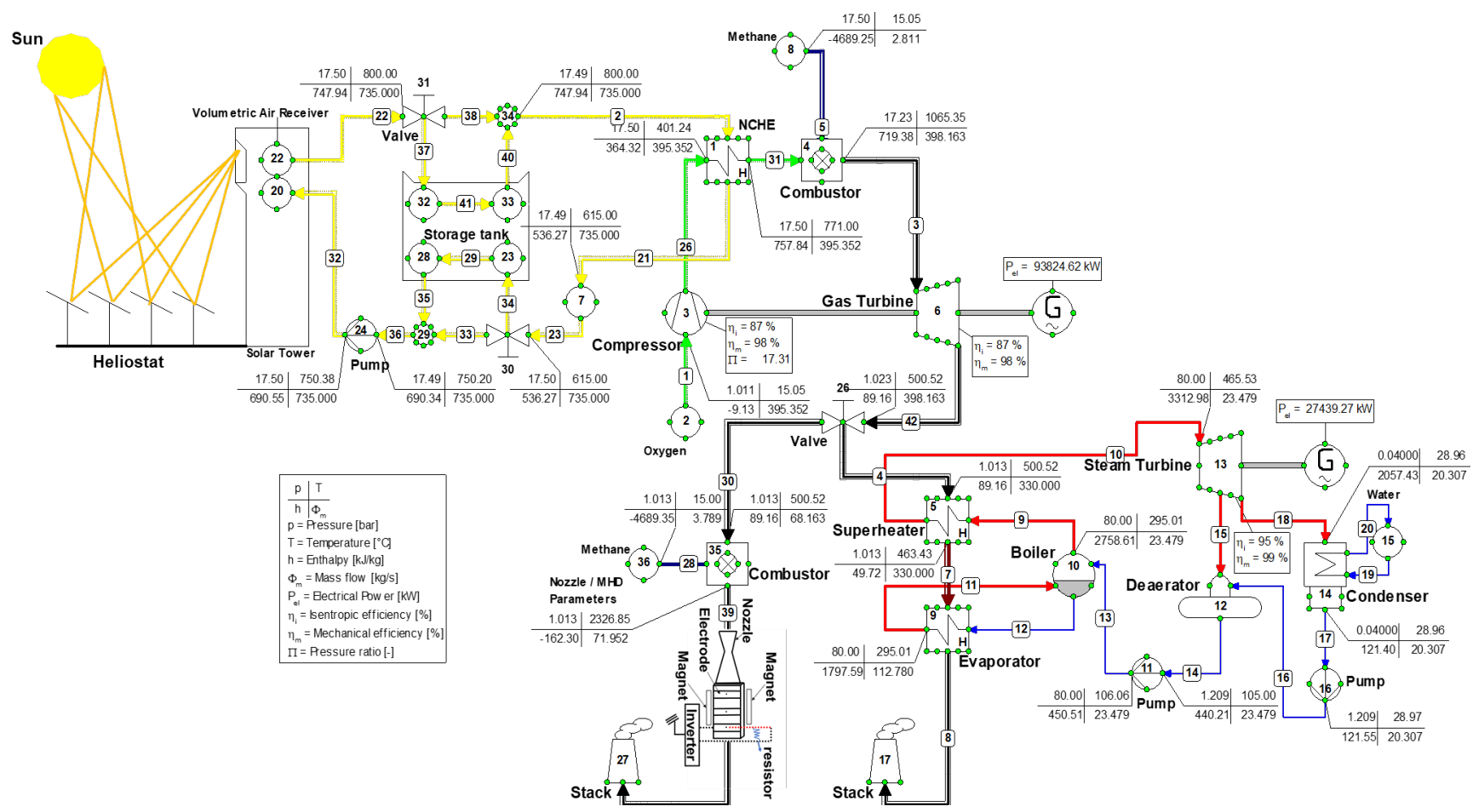

Fig. 6 Flow cycle of the solar hybrid combined cycle power plant (SHCCPP) 
Table 5

The energy performance results of the SHCCPP system

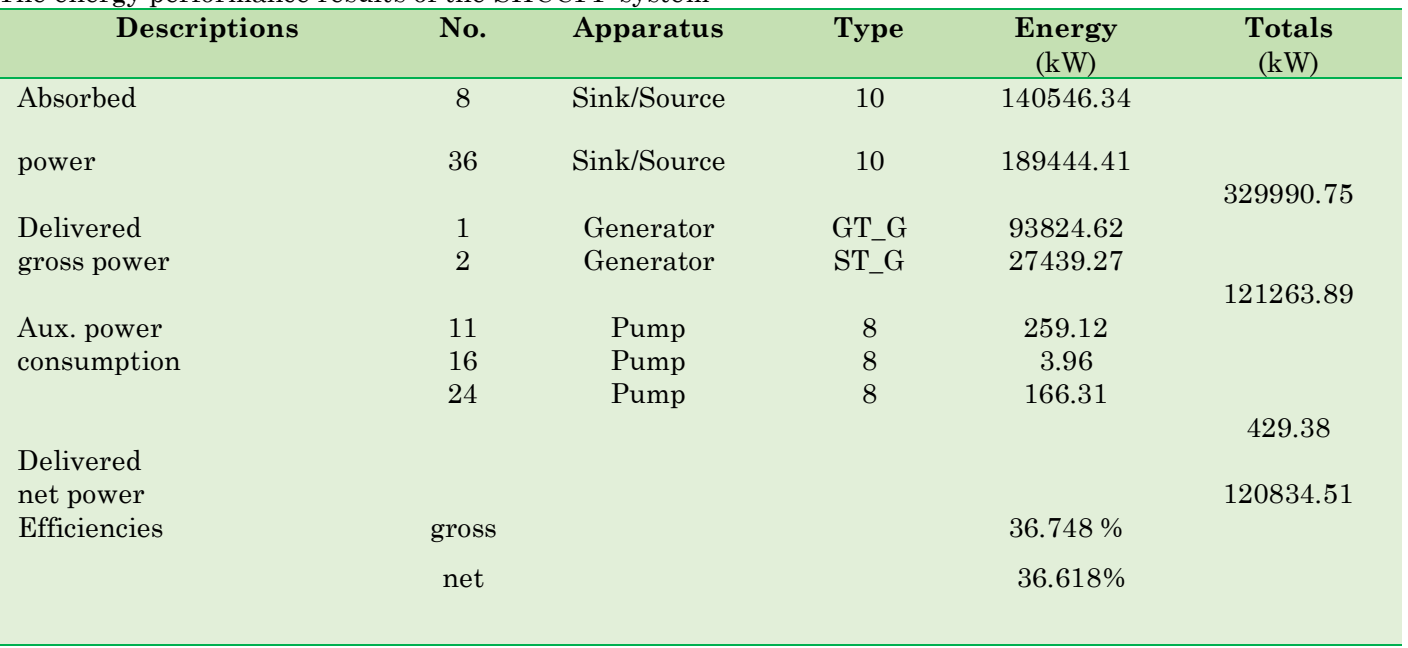

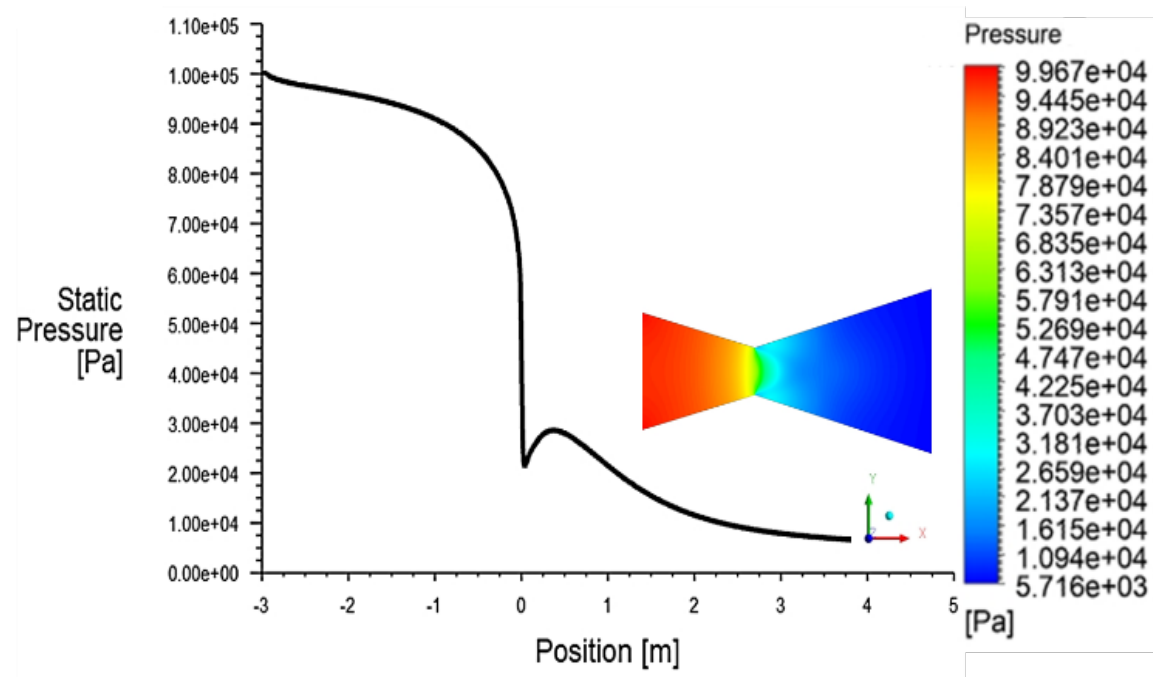

Fig. 7 Plot and contour of flue gas pressure along the nozzle position

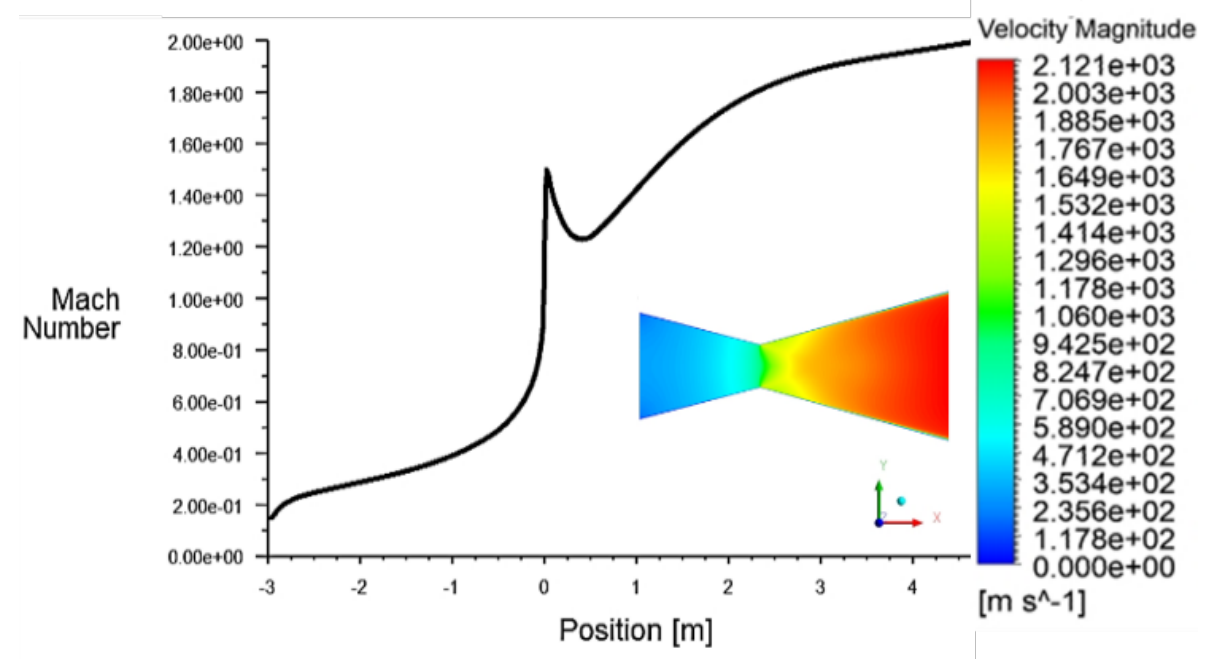

Fig. 8 Plot of Mach number and contour of flue gas velocity along the nozzle position 
Table 6

Net power capacity of the SHCCPPM for several fuel pressure levels

\begin{tabular}{lccc}
\hline Descriptions & \multicolumn{3}{c}{ Fuel pressure levels } \\
\cline { 2 - 4 } & $\mathbf{1 0}$ (bar) & $\mathbf{1 7 . 5}$ (bar) & $\mathbf{2 5}$ (bar) \\
\hline Mass flow rate (kg/s) & 2.81 & 2.81 & 2.81 \\
SHCCPP net efficiency (\%) & 30.5 & 36.6 & 40 \\
SHCCPP net power (MWe) & 98 & 121 & 134 \\
MHD generator power (MWe) & 71 & 71 & 71 \\
SHCCPPM net power (MWe) & 169 & 192 & 205 \\
\hline
\end{tabular}

\subsection{Modelling results of the MHD generator system}

In the present study, a linear shape MHD generator system coupled to a C-D nozzle is integrated as a bottom unit to the SHCCPP system.

\section{- $C-D$ nozzle}

Figure 7 presents the contour $(x-y$ plane, $z=0)$ of the flue gas pressure gradient along the C-D nozzle. The flue gas pressure of $1 \mathrm{e}^{5} \mathrm{~Pa}$ at the nozzle inlet decreased to about $6.46 \mathrm{e}^{4} \mathrm{~Pa}$ at the nozzle throat. From the nozzle throat, the pressure decreased to $5.96 \mathrm{e}^{3} \mathrm{~Pa}$ at the nozzle outlet. The rapid reduction of pressure is due to the shock wave that occurs just after the nozzle throat. These outcomes are comparable to the nozzle inlet and outlet pressures of $55 \mathrm{e}^{5}$ $\mathrm{Pa}$ and $7.23 \mathrm{e}^{4} \mathrm{~Pa}$ reported by Butt and Arshad (2015). Similar reduction of pressure gradients was found in the findings of Deshpande et al. (2014), Khan et al. (2018), Ayeleso and Kahn (2018) and Ahmed et al. (2018). Figure 8 presents the contour ( $\mathrm{x}-\mathrm{y}$ plane, $\mathrm{z}=0$ ) of the flue gas velocity along the C-D nozzle. The flue gas velocity of 296 $\mathrm{m} / \mathrm{s}$ at the nozzle inlet increased to about $925 \mathrm{~m} / \mathrm{s}$ at the nozzle throat. From the nozzle throat, the velocity increased to $2131 \mathrm{~m} / \mathrm{s}$ (Mach number $=2.44$ ) at the nozzle outlet. It is worth noting that while the flue gas velocity increases towards the nozzle outlet, the pressure gradient decreases. These outcomes are comparable to the nozzle inlet and outlet velocities of $148 \mathrm{~m} / \mathrm{s}$ and $2234 \mathrm{~m} / \mathrm{s}$ reported by Butt and Arshad (2015). Similar observations were found in the findings of Deshpande et al. (2014), Khan et al. (2018), Ayeleso and Kahn (2018), Ahmed et al. (2018), and Lee and Kim (2021).

\section{- MHD generator}

The MHD generator modelling results obtained in the present study are compared to those reported by Khalili et al. (2015). In both studies, an MHD generator unit is coupled to a triple combined cycle plant. The major difference is that a linear MHD is incorporated as a bottom unit in the current study, while a de Laval nozzle shape was incorporated as a topping unit by Khalili et al. (2015). When comparing the two systems, the power output is significantly higher in the present study. The differences in the power outputs can be attributed to the generator shape and input parameters.

In the present study, the generator is linear (inlet velocity of $2131 \mathrm{~m} / \mathrm{s}$, Mach number of 2.44 , conductivity of $10 \mathrm{~S} / \mathrm{m}$, magnetic field of $2.5 \mathrm{~T}$ ) and produces a net power of $71 \mathrm{MWe}$ with a conversion efficiency rate of $50 \%$. In Khalili et al. (2015), the generator was analysed with an inlet velocity of $701.71 \mathrm{~m} / \mathrm{s}$ (Mach number $=0.7$ ), a conductivity of $20 \mathrm{~S} / \mathrm{m}$ and a magnetic field of $4 \mathrm{~T}$ at three diverging angles $\left(0^{\circ}, 2.85^{\circ}\right.$ and $\left.5.70^{\circ}\right)$. The net powers obtained were respectively 3.8 MWe, 11.6 MWe and 11.8 MWe, with an efficiency rate of $30.43 \%$. It can be argued that the Laval nozzle generator shape created different structural positions for the magnets, which had affected the distribution of the magnetic flux density in the generator channel (Khalili et al. 2015). It could also be due to the velocity magnitude in the current study which is increased in three-fold. More studies are required to further validate these findings. Table 6 presents the net power capacity of the SHCCPPM under several fuel pressure levels (10 bar, 17.5 bar, and 25 bar). As seen in Table 6, when the fuel pressure applied in the gas turbine is at 10 bar, 17.5 bar and 25 bar, the net powers delivered by the SHCCPP are $98 \mathrm{MWe}, 121 \mathrm{MWe}$ and $134 \mathrm{MWe}$ and the net efficiencies are $30.5 \%, 36.6 \%$ and $40 \%$, respectively. Furthermore, the performance analysis of the SHCCPPM indicates that at the different fuel pressure levels, a net nominal capacity of $169 \mathrm{MWe}, 192 \mathrm{MWe}$, and 205 MWe are obtained. These findings show that the overall power outputs of the triple combined cycle increased with an increase in the fuel pressure levels (10 to 25 bar). In addition, the incorporation of the MHD generator at the bottom of the SHCCPPM increases the overall power delivered.

\section{Conclusion}

The energy performance of a MW-class solar hybrid system (SHCCPPM) for large power generation has been modelled in this study. To set up this system, a Mercury $50^{\mathrm{TM}}$ gas turbine (Brayton cycle), a solar thermal plant, a steam turbine (Rankine cycle) and a magnetohydrodynamics generator were combined. The energy performance of the overall system was investigated under oxy-fuel combustion conditions and compared with a Siemens SGT5-4000F plant to demonstrate possible benefits and drawbacks.

The performance analysis of the SHCCPP system showed that with an increase in the pressure rates at the inlet of the GT combustor, the net power and efficiency of the system improve. The overall power delivered by the entire system is attributed to the energy extracted from the GT exhaust in the RC and the bottom MHD generator 
cycle. The incorporation of solar energy and oxy-fuel combustion to the GT reduces fuel mass rate. However, the increase in the inlet temperature of the GT combustor due to the addition of solar energy led to a relative decrease in the efficiency of the GT combustion process.

From the above observations, the solar hybrid system can be considered as a potential alternative to the conventional power plants. This system offers potential benefits such as reduction in fuel consumption and $\mathrm{CO}_{2}$ emissions.

\section{Acknowledgements}

The authors would like to thank the Cape Peninsula University of Technology for providing financial supports. The authors also acknowledge the Asimptote and Ansys companies for providing the software used for this work.

\section{Nomenclature}

Symbols

$\eta_{c} \quad$ Compressor isentropic efficiency [\%]

$T_{1} \quad$ Compressor inlet temperature $\left[{ }^{\circ} \mathrm{C}\right]$

$\mathrm{T}_{2}{ }^{\prime} \quad$ Compressor isentropic outlet temperature $\left[{ }^{\circ} \mathrm{C}\right]$

$\mathrm{T}_{2} \quad$ Compressor outlet temperature $\left[{ }^{\circ} \mathrm{C}\right]$

$r_{c}, \quad$ Compressor pressure ratio [dimensionless]

$\gamma_{a} \quad H e a t$ capacity ratio for air or $\mathrm{O}_{2}$ [dimensionless]

$T_{3} \quad$ Flue gas temperature after combustion $\left[{ }^{\circ} \mathrm{C}\right]$

$T_{4}{ }^{\prime} \quad$ The reversible adiabatic expansion $\left[{ }^{\circ} \mathrm{C}\right]$

$T_{4} \quad$ Actual turbine discharge temperature $\left[{ }^{\circ} \mathrm{C}\right]$

$\gamma_{g} \quad$ Heat capacity ratio for flue gas [dimensionless]

$\eta_{T} \quad$ Turbine isentropic efficiency [\%]

$T_{5} \quad$ Heat exchanger temperature $\left[{ }^{\circ} \mathrm{C}\right]$

$\eta_{N C H E} \quad$ Heat exchanger efficiency [\%]

$m_{a} \quad$ Mass flow rate for air or pure oxygen $[\mathrm{kg} / \mathrm{s}]$

$c p_{a} \quad$ Specific heat for air or pure oxygen [kJ/kg.K]

$W_{\mathrm{C}} \quad$ Compressor work [kJ/kg.K]

$W_{\mathrm{GT}} \quad$ Gas turbine work [kJ/kg.K]

$c p_{g} \quad$ Specific heat capacity of flue gas [kJ/kg.K]

$r_{T} \quad$ Turbine pressure ratio [dimensionless]

$W_{\text {ratio }} \quad$ Turbine work ratio [dimensionless]

$W_{\text {net_GT }} \quad$ Gas turbine net power $[\mathrm{kW}]$

$\eta_{B C} \quad$ Brayton cycle efficiency [\%]

$W_{S T} \quad$ Steam turbine work [kW]

$W_{P} \quad$ Power of pump $[\mathrm{kW}]$

$W_{\text {net_ST }} \quad$ Steam turbine net power $[\mathrm{kW}]$

$\eta_{R C} \quad$ Thermal efficiency of Rankine cycle [\%]

$m_{R C} \quad$ Mass flow rate to Rankine cycle [kg/s]

$m_{H S} \quad$ Mass flow rate of heat carrier $[\mathrm{kg} / \mathrm{s}]$

$c p_{H S M} \quad$ Specific heat capacity of heat source medium

$T_{S} \quad$ Steam turbine inlet temperature $\left[{ }^{\circ} \mathrm{C}\right]$

$T_{\text {exit }} \quad$ Steam turbine exit temperature $\left[{ }^{\circ} \mathrm{C}\right]$

$h_{1} \quad$ Entalphy of pump [kJ/kg]

$h_{5} \quad$ Entalphy of condenser [kJ/kg]

$h_{3} \quad$ Entalphy of preheaters $[\mathrm{kJ} / \mathrm{kg}]$

$h_{4} \quad$ Entalphy of turbine $[\mathrm{kJ} / \mathrm{kg}]$

$W_{A U X} \quad$ Auxiliary work $[\mathrm{kW}]$

$W_{C C}{ }^{\text {net }}$ Combined cycle net power [kW]

$\eta_{C C}{ }^{\text {net }} \quad$ Combined cycle net efficiency [\%]

$Q_{G T} \quad$ Heat supplied to the gas turbine [kW]

$Q_{S T} \quad$ Heat supplied to the steam turbine [kW]

$m_{\text {fuel }} \quad$ Fuel mass flow rate $[\mathrm{kg} / \mathrm{s}]$

$L H V_{\text {fuel }} \quad$ Lower heating value of fuel $[\mathrm{kJ} / \mathrm{kg}]$

$\mathrm{V} \quad$ Open-circuit voltage [V]

$v \quad$ Fluid velocity $[\mathrm{m} / \mathrm{s}]$

$l \quad$ Distance between the electrodes [m]

$B \quad$ Magnetic flux density [T]

$V_{\max } \quad$ Maximum voltage [V]

I $\quad$ Current [A]

$I_{\max } \quad$ Maximum current [A]

\begin{tabular}{|c|c|}
\hline$R_{I}$ & Internal resistance $[\Omega]$ \\
\hline$R_{L}$ & External load resistance $[\Omega]$ \\
\hline$P_{\text {out }}$ & Electric power $[\mathrm{W}]$ \\
\hline$P_{\max }$ & Maximum power $[\mathrm{W}]$ \\
\hline$\sigma$ & Electrical conductivity [S/m] \\
\hline$A$ & Electrode surface area $\left[\mathrm{m}^{2}\right]$ \\
\hline$k$ & Electrical load factor [dimensionless] \\
\hline$\eta$ & MHD conversion efficiency [\%] \\
\hline
\end{tabular}

Abbreviations

$\begin{array}{ll}\text { SPT } & \text { Solar power tower } \\ \text { CSP } & \text { Concentrated solar power } \\ \text { CRS } & \text { Central receiver system } \\ \text { GT } & \text { Gas turbine } \\ \text { ST } & \text { Steam turbine } \\ \text { HTF } & \text { Heat transfer fluid } \\ \text { CO }_{2} & \text { Carbon dioxide } \\ \text { CCGTs } & \text { Combined cycle gas turbines } \\ \text { MW } & \text { Megawatt } \\ \text { BC } & \text { Brayton cycle } \\ \text { RC } & \text { Rankine cycle } \\ \text { MHD } & \text { Magnetohydrodynamic } \\ \text { OEC } & \text { Oxygen Enhanced Combustion } \\ \mathrm{O}_{2} & \text { Oxygen } \\ \text { NCHE } & \text { Non-contact heat exchanger } \\ \text { HRSG } & \text { Heat recovery steam generator } \\ \text { T-s } & \text { Temperature-entropy } \\ \text { CC } & \text { Combustion chamber } \\ \text { C-D } & \text { Convergent-divergent } \\ \text { CFD } & \text { Computational fluid dynamic } \\ \text { SHCCPP } & \text { Solar hybrid combined cycle power plant } \\ \text { SHCCPPM Solar hybrid combined cycle power plant and MHD } & \text { generator } \\ & \end{array}$

\section{References}

Ahmad, A.D., Abubaker, A.M., Najjar, Y.S.H. \& Manaserh, Y.M.A. (2020). Power boosting of a combined cycle power plant in Jordan: An integration of hybrid inlet cooling \& solar systems, Energy Conversion and Management, 214,112894. DOI: 10.1016/j.enconman.2020.112894.

Ahmed, H.O., Hesham, E.A. \& Hamza, H.S. (2018). CFD Analysis of De Laval Nozzle Geometry \& Effect of Gas Pressure Variation at the Entrance. International Journal for Research in Applied Science \& Engineering Technology, 6, 350-361. https://www.ijraset.com/archive-detail.php?AID=81 (accessed 26 April 2021)

Ajith, K.R. \& Jinshah, B.S. (2013). Magnetohydrodynamics Power Generation. International Journal of Scientific and Research Publications. 3, 1-11. ISSN: 2250-3153

Aldali, Y. \& Morad, K. (2016). Numerial simulation of the integrated solar/North Benghazi combined power plant. Applied Thermal Engineering, 108, 785-792. DOI: https://doi.org/10.1016/j.applthermaleng.2016.07.178

Allam, R.J., Palmer, M.R., William Brown, G., Fetvedt, J., Freed, D., Nomoto, H., Itoh, M., Okita, N. \& Jones, C. (2013). High Efficiency and Low Cost of Electricity Generation from Fossil Fuels While Eliminating Atmospheric Emissions, Including Carbon Dioxide. Energy Procedia, 37, 1135-1149. DOI: 10.1016/j.egypro.2013.05.211.

Amelio, M, Ferraro, V, Marinelli, V. \& Summaria, A. (2014). An evaluation of the performance of an integrated solar combined cycle plant provided with air-linear parabolic collectors. Energy, 69, 742-8. DOI: 10.1016/j.energy.2014.03.068.

Anderson, R.E., Mac Adam, S., Viteri, F., Davies, D.O., Downs, J.P. \& Paliszewski, A. (2008). Adapting gas turbines tozero emission oxy-fuel power plants. In Proceedings of the ASME Turbo Expo 2008: Power for Land, Sea, and Air, Berlin, Germany, 9-13 June, 781-791. DOI: 10.1115/GT2008-51377

Antonanzas, J, Jimenez, E, Blanco, J. \& Antonanzas-Torres, F. (2014). Potential solar thermal integration in Spanish combined cycle gas turbines. Renewable and Sustainable Energy Reviews, 37, 36-46. DOI: 10.1016/j.rser.2014.05.006. 
Anumaka, M.C. (2014). Feasible Classification of Magnetohydrodynamic (MHD) Generating Power Plant. International Journal of Innovative Technology and Research, 2, 1078-1084. ISSN: $2320-5547$

http://www.ijitr.com/index.php/ojs/article/view/347 (accessed 9 November 2020)

Augsburger, G., Das, A.K., Boschek, E. \& Clark, M.M. (2015). Thermo-Mechanical and Optical Optimization of the Molten Salt Receiver for a Given Heliostat Field. SolarPACES Conference proceedings, 030005. DOI: 10.1063/1.49490

Augsburger, G. (2013). Thermo-economic optimisation of large solar tower power plants. Doctoral Thesis, École Polytechnique Federale de Laussane. DOI: 10.5075/epflthesis-5648

Ayeleso, A.O. \& Kahn, M.T.E. (2018). Modelling of a combustible ionised gas in thermal power plants using MHD conversion system in South Africa. Journal of King Saud University Science, 30, 367-374. DOI: 10.1016/j.jksus.2017.01.007

Baskar, P. \& Senthilkumar, A. (2016). Effect of oxygen enriched combustion on pollution and performance characteristics of a diesel engine. Engineering Science and Technology, an International Journal, 19, 438-443. DOI: 10.1016/j.jestch.2015.08.011

Bedick, C.R., Kolczynski, L. \& Woodside, C.R. (2017). Combustion plasma electrical conductivity model development for oxy-fuel MHD applications. Combustion and Flame, 181, 225-238. DOI: 10.1016/j.combustflame.2017.04.001

Behar, O., Khellaf, A. \& Mohammedi, K. (2013). A review of studies on central receiver solar thermal power plants. Renewable and Sustainable Energy Reviews, 23, 12-39.

Buck, R., Bra"uning, T., Denk, T., Pfa"nder, M., Schwarzbo"zl, P. \& Tellez, F. (2002). Solar-hybrid gas turbine-based power tower systems (REFOS). Journal of Solar Energy Engineering, 124, 2-9. DOI: 10.1115/1.1445444

Buck, R., Giuliano, S. \& Uhlig, R. (2017). Central tower systems using the Brayton cycle. Elsevier Ltd. DOI: 10.1016/B978-008-100516-3.00016-2.

Butcher, C.J. \& Reddy, B.V. (2007). Second law analysis of a waste heat recovery based power generation system. International Journal of Heat and Mass Transfer, 50, 2355-2363. DOI: 10.1016/j.ijheatmasstransfer.2006.10.047

Butt, A.H. \& Arshad, A. (2015). Design and analysis of a clustered nozzle configuration and comparison of its thrust. Student Research Paper Conference. 2, 105-109.

Deshpande, N.D., Vidwans, S.S., Mahale, P.R., Joshi, R.S. \& Jagtap, K.R. (2014). Theoretical \& CFD analysis of De Laval Nozzle. International Journal of Mechanical and Production Engineering, $\quad 2, \quad 33-36 . \quad$ DOI: http://iraj.doionline.org/dx/IJMPE-IRAJ-DOIONLNE-640

Dumitrascu, G., Marin, O., Charon, O. \& Horbaniuc, B. (2001). The influence of the compression interstage cooling by adiabatic humidification of the steam injection and of the oxygen enriched combustion upon the gas turbine cogeneration systems. 2nd Heat Powered Cycles Conference Conservatoire national des arts et métiers, Paris.

Eason, G., Noble, B. \& Sneddon, I.N. (2016). Energy Systems in Electrical Engineering. Handbook of Solar Energy Theory, Analysis and Applications, Springer. DOI: 10.1007/978-98110-0807-8.

EL Hassani, S.E., Ouali, H.A.L., Raillani, B., Moussaoui, M.A., Mezrhab, A. \& Amraqui, S. (2020). Thermal Performance of Solar Tower Using Air as Heat Transfer Fluid under MENA Region Climate. 5th International Conference on Renewable Energies for Developing Countries (REDEC), Marrakech, Morocco, Morocco, 1-4.

Ferrari, N., Mancuso, L., Davison, J., Chiesa, P., Martelli, E. \& Romano, M.C. (2017). Oxy-Turbine for Power Plant with CO2 Capture. Energy Procedia, 114, 471-480. DOI: 10.1016/j.egypro.2017.03.1189

Garcia, P., Ferriere, A., Flamant, G., Costerg, P., Soler, R. \& Gagnepain, B. (2008). Solar field efficiency and electricity generation estimations for a hybrid solar gas turbine project in France. Journal of Solar Energy, 82, 189-197. DOI: $10.1115 / 1.2807211$
Giuliano, S., Schillings, C., Hoyer-Klick, C., Al Nuaimi, S. \& Al Obaidli, A. (2008). USHYNE - Upscaling of solar-hybrid gas turbine cogeneration units, Final Report.

Heller, P., Pfänder, M., Denk, T., Tellez, F., Valverde, A., Fernandez, J. \& Ring, A. (2006). Test and Evaluation of a Solar Powered Gas Turbine System. Solar Energy, 80, 1225 1230. DOI: https://doi.org/10.1016/j.solener.2005.04.020

Hischier, I., Hess, D., Lipiński, W., Modest, M. \& Steinfeld, A. (2009). Heat Transfer Analysis of a Novel Pressurized Air Receiver for Concentrated Solar Power via Combined Cycles. Journal of Thermal Science and Engineering Applications, 1, 1-6 (041002). DOI: 10.1115/1.4001259

Ho, C.K. \& Iverson, B.D. (2014). Review of high temperature central receiver designs for concentrating solar power. Renewable and Sustainable Energy Reviews, 29, 835-846. DOI: 10.1016/j.rser.08.099

Ho, C.K., Khalsa, S.S. \& Siegel, N.P. (2009). Modelling on-sun tests of a prototype solid particle receiver for concentrating solar power processes and storage. Proceedings of ES2009 Energy Sustainability, July 19-23, San Francisco, California USA. DOI: 10.1115/ES2009-90035

Hong, J., Chaudhry, G., Brisson, JG., Field, R., Gazzino, N. \& Ghoniem, A. (2009). Analysis of oxy-fuel combustion power cycle utilizing a pressurized coal combustor. Energy, 34, 1332-1340. DOI: 10.1016/j.energy.2009.05.015

Horbaniuc, B., Marin, O., Dumitrascu, G. \& Charon, O. (2004). Oxygen enriched combustion in supercritical steam boilers, Energy, 29, 427-448. DOI: 10.1016/j.energy.2003.10.009

Hoseinzadeh, S., Ghasemi, R. \& Heyns, P.S. (2020a). Application of hybrid systems in solution of low power generation at hot seasons for micro hydro systems. Renewable Energy, 160, 323332. DOI: 10.1016/j.renene.2020.06.149.

Hoseinzadeh, S., Ghasemi, R., Javadi, M.A. \& Heyns, P.S. (2020b). Performance evaluation and economic assessment of a gas power plant with solar and desalination integrated systems. Desalination and Water Treatment, 174, 11-25. DOI: $10.5004 / \mathrm{dwt} .2020 .24850$

Jabbar, M.Q. (2014). Improvement of performance operation and cycle efficiency of Al Anbar combined power plant. FPEPM 2014: Annual Conference of the Faculty of Power Engineering and Power Machines, Bulgaria.

Kadhim, H.J., Kadhim, T.J. \& Alhwayzee, M.H. (2019). A Comparative Study of Performance of Al-Khairat Gas Turbine Power Plant for Different Types of Fuel. IOP Conference Series: Materials Science and Engineering, 671, 012015. DOI: 10.1088/1757-899X/671/1/012015

Khan, S.A., Aabid, A. \& Baig, M.A.A. (2018). CFD analysis of CD nozzle and effect of nozzle pressure ratio on pressure and velocity for suddenly expanded flows. International Journal of Mechanical and Production Engineering Research and Development, $\quad 8, \quad 1147-1158 . \quad$ DOI: 10.24247/ijmperdjun2018119

Kalina, J. (2012). Comparative analysis of alternative configurations of the mercury 50 recuperated gas-turbinebased biomass integrated gasification combined heat and power (BIGCHP) plant. Energy Fuel, 26, 6452-6465. DOI: 10.1021/ef201624h

Kalogirou, S.A. (2011). Concentrating solar power plants for electricity and desalinated water production. World Renewable Energy Congress, 8-13 May, Linkoping, Sweden. DOI: $10.3384 /$ ecp 110573881

Kayabasß1, E., Furtun, F. \& Özkaymak, M. (2017). Investigation of Heat Recovery and Saving Potential of Hot Stoves in Blast Furnaces Investigation of Heat Recovery and Saving Potential of Hot Stoves in Blast Furnaces. 3rd Iron and Steel Symposium (UDCS'17), 20-24 January. http://indexive.com/Paper/2160/investigation-of-heatrecovery-and-saving-potential-of-hot-stoves-in-blast-furnaces (accessed 10 November 2020)

Kayukawa, N. (2004). Open cycle magnetohydrodynamic electrical power generation: a review and future perspectives. Progress in Energy and Combustion Science, 30, 33-60. DOI: 10.1016/j.pecs.2003.08.003

Khalili, S., Dehkordi, A.J. \& Giahi, M.H. (2015). Investigating the effect of channel angle of a subsonic MHD (Magneto-HydroDynamic) generator on optimum efficiency of a triple 
combined cycle. Energy, 85, 543-555. DOI: 10.1016/j.energy.2015.03.064

Korzynietz, R., Brioso, J.A., del Río, A., Quero, M., Gallas, M., Uhligc, R., Ebert, M, Buck, R. \& Teraji, D. (2016). Solugas Comprehensive analysis of the solar hybrid Brayton plant. Solar Energy, 135, 578-589. DOI: 10.1016/j.solener.2016.06.020

Kotowicz, J., Michalski, S. \& Brzęczek, M. (2019). The Characteristics of a Modern Oxy-Fuel Power Plant. Energies, 12, 1-34. DOI: 10.3390/en12173374

Lee, G.H., \& Kim, H.R. (2021). Numerical study of Faraday-type nitrogen plasma magnetohydrodynamic generator. Journal of the Korean Physical Society, 78, 600-606. DOI: 10.1007/s40042-021-00116-z

Lundberg, W.L., Veyo, S.E. \& Moeckel, M.D. (2003). A highefficiency solid oxide fuel cell hybrid power system using the Mercury 50 advanced turbine systems gas turbine. ASME Journal of Engineering for Gas Turbines and Power, 125, 5158. DOI: $10.1115 / 1.1499727$

Malan, K.J. (2014). A Heliostat Field Control System. Master of Engineering Dissertation, Stellenbosch University.

Manente, G. (2016). High performance integrated solar combined cycles with minimum modifications to the combined cycle power plant design. Energy Conversion and Management, 111, 186-97. DOI: 10.1016/j.enconman.2015.12.079.

Moran, M. \& Shapiro, H. (2010). Fundamentals of Engineering Thermodynamics. $6^{\text {th }}$ ed. Wiley India Pvt. Limited. ISBN: 9781-119-39138-8

Nowak, W., Złotkowski, M. \& Alharbi, A.A. (2019). Analysis of a micro-oxy gas turbine for variable oxidizer and fuel parameters. Research \& Development in Power Engineering, 137, 1-6, 01005. DOI: 10.1051/e3sconf/201913701005

Nurhilal, O., Mulyana, C., Suhendi, N. \& Sapdiana, D. (2016). The simulation of organic Rankine cycle power plant with npentane working fluid. AIP Conference Proceedings, 1712, 040003-1-040003-5. DOI: 10.1063/1.4941880

Oyedepo, S.O., Fagbenle, R.O. \& Adefila, S.S. (2017). Modelling and assessment of effect of operation parameters on gas turbine power plant performance using first and second laws of thermodynamics. American Journal of Engineering and Applied Sciences, 10, 412-430. DOI: 10.3844/ajeassp.2017.412.430

Parsodkar, R.R. (2015). Magneto Hydrodynamics Generator. Journal of Advance Research in Electrical \& Electronics Engineering, 2, 01-07. ISSN: 2208-2395 https://www.nnpub.org/index.php/EEE/article/view/210 (accessed 9 November 2020)

Petrakopoulou, F., Sánchez-Delgado, S., Marugán-Cruz, C. \& Santana, D. (2017). Improving the efficiency of gas turbine systems with volumetric solar receivers. Energy Conversion and Management, 149, 579-592. DOI: 10.1016/j.enconman.2017.07.058

Pitz-Paal, R., Dersch, J. \& Milow, B. (2005). European concentrated solar thermal road-mapping (ECOSTAR). EU funded study, SES6-CT-2003-502578. DOI: https://cordis.europa.eu/project/id/502578

Poonthamil, R., Prakash, S. \& Anand Kumar Varma, S. (2016). Enhancement of Power Generation in Thermal Power Plant Using MHD System. IOSR Journal of Mechanical and Civil Engineering, 1, 142-146. DOI: 10.9790/1684-130502142146
Poživil, P., Aga, V., Zagorskiy, A. \& Steinfeld, A. (2014). A pressurized air receiver for solar-driven gas turbines. Energy Procedia, 49, 498-503. DOI: 10.1016/j.egypro.2014.03.053

Rahman, M.M., Ibrahim, T.K., Kadirgama, K., Mamat, R. \& Bakar, R.A. (2011). Influence of operation conditions and ambient temperature on performance of gas turbine power plant. Advanced Materials Research, 189-193, 3007-3013. DOI: 10.4028/www.scientific.net/AMR.189-193.3007

Rajesh, R. \& Kishore, P.S. (2018). Thermal Efficiency of Combined Cycle Power Plant. International Journal of Engineering and Management, 8, 229-234. DOI: 10.31033/ijemr.8.3.30

Saghafifar, M. \& Gadalla, M. (2016). Thermo-economic analysis of conventional combined cycle hybridization: United Arab Emirates case study. Energy Conversion and Management, 111, 358-74. DOI: 10.1016/j.enconman.2015.12.016.

Self, S., Rosen, M. \& Reddy, B. (2018). Effects of Oxy-Fuel Combustion on Performance of Heat Recovery Steam Generators. European Journal of Sustainable Development Research, 2, 22. DOI: 10.20897/ejosdr/69787

Sivaram, A.R., Kanimozhivendhan, G., Rajavel R. \& Durai Raj, V.P. (2015). Performance Investigation of a closed cycle Magneto Hydrodynamics Power plant with liquid metal as heat source. Indian journal of science and technology, 8, 1-6. DOI: $10.17485 / \mathrm{ijst} / 2015 / \mathrm{v} 8 \mathrm{i} 21 / 78473$

Song, T.W., Sohn, J.L., Kim, T.S. \& Ro, S.T. (2006). Performance characteristics of a MW-class SOFC/GT hybrid system based on a commercially available gas turbine. Journal of Power Sources, 158, 361-367. DOI: 10.1016/j.jpowsour.2005.09.031

Spelling, J.D. (2013). Hybrid solar gas-turbine power plants - a thermo-economic analysis. Doctoral thesis. KTH Royal Institute for technology, Stockholm.

Solgate Report, Ormat, Ciemat, Dlr, Solucar, Tuma. (2005). Solar hybrid gas turbine electric power system. ISBN 92-894-45920 .

Takayanagi, S., Takahashi, K., Sasaki, T., Aso, T. \& Harada, N. (2014). Theoretical Power Output from a Capacitive-Coupled Power Extraction Magneto-hydrodynamic Generator with a Sinusoidal Alternating Magnetic Field. Plasma and Fusion Research, 9, 1206094. DOI: 10.1585/pfr.9.1206094

Tchanche, B.F., Loonis, P., Petrissans, M. \& Ramenah, H. (2013). Organic Rankine cycle systems Principles, opportunities and challenges. In: Microelectronics (ICM), 2013, 25th International Conference on Microelectronics, IEEE, 1-4, Beirut. DOI: 10.1109/icm.2013.6735014

Vogel, W. (2010). Large-scale solar thermal power: technologies, costs, and development. Wiley-VCH. ISBN: 978-3-527-405152 .

Wang, S., Fu, Z., Sajid, S., Zhang, T. \& Zhang, G. (2018). Thermodynamic and Economic Analysis of an Integrated Solar Combined Cycle System. Entropy, 20, 313. DOI: $10.3390 / \mathrm{e} 20050313$

Wallentinsen, B.S. (2016). Concentrated Solar Power Gas Turbine Hybrid with Thermal Storage. Master Thesis, Norwegian University of Science and Technology. DOI: 10.1016/j.rser.2013.02.017

Zhang, H.L., Baeyens, J., Degrève, J. \& Cacères, G. (2013). Concentrated solar power plants: Review and design methodology. Renewable and Sustainable Energy Reviews, 22, 466-481. DOI: 10.1016/j.rser.2013.01.032 